\title{
Empirical study of E-Travel Adoption among Small Enterprises in Developing Country
}

\author{
Vera Pujani" \\ Department of Management, Andalas University, Limau Manih \\ Padang, 25163, Indonesia
}

Email:vpujani@gmail.com

\begin{abstract}
The objective of this paper is to test the success factor of e-travel model among small travel enterprises (STEs) in Indonesia. The data was collected by e-survey via My3q free online survey. Respondents were 145- users of travel websites chosen employing purposive sampling technique. Research variables measured were factors of Enjoyment, Usefulness, Ease of use, Self Efficacy, Use, Satisfaction, Trust and Loyalty. These variables were tested in 11 hypothesis. The structural equation modelling (SEM) using SmartPLS 2.0 in data analysis was worked. The result of this study illustrated that nine of eleven hypothesis have contribution significantly and the rest conversely. However, perceive of usefulness did not influence to e-travel adoption and trust to loyalty during browsing travel websites. Finally, examining the success model of e-travel adoption in different provinces and travel websites is as the suggestion of further research.
\end{abstract}

Keywords: E-commerce, small travel enterprises, Indonesia.

\section{Introduction}

The role of information technology in operating business activities has been identified as the success tool of company's performance. However, not only for organizational performance, but, there are numerous unsuccessful implemetation of new information technology uses, including costly IT investment, low performance, less value and contributions to productivity, quality and competitiveness ${ }^{1}$ especially in small enterprises. The unsuccessful implemtation of IT/IS could be caused by: (1) gaps between theory, conceptual frameworks and practice; (2) objective gaps of information systems strategic planning and (3) poor establishment of information systems evaluation methods ${ }^{2}$. Briefly, the success and unsuccessful in using information technologies indicates some matters and difficulties with different causes ${ }^{3}$.

Website is one of the applications in terms of the information technology and indicates as an e-commerce tool in operating the cyber business activity. New economic category such as e-commerce has been studied and analyzed multirole and interdisciplinary and defined as the changing of traditional trade model to be an electronic model by using information and telecommunication technologies and system ${ }^{4}$ (Hyperlink, image map, home page, web browser, web page, or WWW (World Wide Web) are the term used for website which are often interchangeable ${ }^{5}$.

The use of e-commerce system in the travel company, potentially change the way of company activities in doing business transactions. The travel company tends to work with business partners between travel agent with its supplier (e.g Airline company, Hotel), and also the relationship with its consumers. Etravel website is the most frequently visited online information facilities by travelers ${ }^{6}$. There are many travel planners in the world search for tourism in etravel website. Tourism is one of the world's biggest industries which adopts internet as medium for ebusiness revolution. It is used as a tool to attract internet users to use e-travel website.

The development of this system can categorize as innovation process that potential to be key success factor on tourism industry). The successful of the travel company in adopting and developing the concept of ebusiness and e-commerce ensure sustainability of company because of their superior ability in satisfied the customer ${ }^{7}$. E-commerce dominated business activities in all over the world, since e-commerce 
delivers a quick access and less expense. The increasing from number of e-business player by each years with percentage almost $34,46 \%$ in develop countries and $27,83 \%$ in developing countries ${ }^{8}$. In Indonesia ecommerce also became the new potential area, in 2012 total e-commerce transaction reach IDR 330 Trillion which is equal to $1 / 5$ National Budgeting in that year ${ }^{9}$.

The objective of this research is to test the success factor of e-travel model among small travel enterprises (STEs) in Indonesia indicating the developing country.

The following sections are organized as follows; presents the background of the website and then it will be followed by literature review. Thus, the third section explains the research procedure and is continued by fourth section to present toward results of the study. Finally, this article is ended by the discussion and conclusion of this study

\section{Literature Review}

Adoption model of e-commerce and e-travel is extended a theory acceptance model (TAM) by Davis ${ }^{10}$ and empirical related research. The study addresses to user acceptance behaviour in using the new information technology especially internet ${ }^{11,12}$. The current research tested TAM and its consequences including the use of etravel website and factors of satisfaction, trust and loyalty.

\subsection{E-travel Dimension}

The adoption of internet technology and website systems by travel agencies (e-travel) has been successfully changed business mechanism in tourism industry. These changes include the additional value and usefulness for customers in improving of their activities in e-commerce business model. The reprogramming of e-commerce processes and services should be aimed attracting new consumers, satisfying their needs and increasing the number of loyal customers ${ }^{13}$. Gaining trust and guaranteeing their protection for a long term will strengthen the position of intermediaries in the distribution chain of tourism and their competitive advantages.

The e-travel reated to the user activities using presence websites to search related information toward travel industries. By using e-travel websites, users would be able to easy find more about what they are going to find in the website. Actual system refers to (,how often ${ }^{\text {ee }}$ ) and the volume of system use (,how much $^{\text {ee }}$ by the user. Davis ${ }^{10}$ in Technology Acceptance Model (TAM) has earlier postulated that two beliefs, known as the perceived usefulness and perceived ease of use, determine the attitudes of peopasserts that one $e^{\text {ee }}$ behavioral intention influences actual system usage. le toward using a particular system and such attitude together with PU and then will determine use intention and furthermore, this would lead to the actual use of the system $^{14}$.

The satisfaction of website visitors is identified as a success factor in tourism industries ${ }^{15}$. Satisfaction presents the degree of business's product or service performance and macths with customet expectations ${ }^{16}$. Users satisfaction indicates as an important predictor of online consumer behavior and the success of a webbased system ${ }^{17}$. Additionally, It also measurement for success of information system or any several standardized instruments that have been developed and tested $^{18}$. Satisfaction related to also a customer emotional responses in evaluating the discrepancy between expectation of service and perception of actual performance $^{16}$. The performance perception was gained through physical interaction between the business, product and services of the business ${ }^{18}$. Such customers are satisfied during using e-travel website, that, they will tend to repurchase, loyal, and positive word of mouth promotion ${ }^{19}$. The importance of users satisfaction in e-travel prosessing and it defines as the reaction or feeling of a customer in relation to his/her experience with all aspects of an e-commerce system ${ }^{20}$.

The perception of the trust is identified as a party in believe with the others party ${ }^{21}$. Accordingly, trust is the most widely examined and confirmed constructs in the relationship marketing research. Trust commonly discussed that have-related with behavioral intentions in E-commerce include sharing personal information, making a one time or repeating purchase, or acting on information provided by an e-vendor ${ }^{22}$. In this study defines trust is a set of specific beliefs dealing with integrity- trustee honesty and promise keeping- a trustor believe that a trustee makes good faith agreements, tells the truth, acts ethically, and fulfills promises. Benevolence- is the extent to which a trustee is believed want to do good a trustor, Competence - ability of trustee to do what trustor needs ${ }^{23}$.

Sanchez-Franco ${ }^{24}$, identifies that aesthetics and usability of travel websites increase user satisfaction and impact on trust and commitment of website users. The study indicated that there were substantial genders differences both in terms of attitudes to information channels and travel Website functionality preferences ${ }^{25}$. In general, males and females are likely to differ in information processes and decision making. Based on tourist perceptions of online travel, it illustrates that online and traditional distributional channels could coexisted delivering tourism services. This finding presents that tourist still required the professional service and advice offered ${ }^{26}$. 


\subsection{Conceptual Frameworks}

2.2.1 Perceived Enjoyment, Usefulness, Ease of Use and Self Efficacy

Using website perceives numerous success variables including self-efficacy, enjoyment, learning goal orientation $^{27}$. There are some significant relationships between these variables; such as enjoyment has significant impact on ease of use and usefulness and was stronger determinant of usefulness than ease of use. Sun and Zhang ${ }^{28}$ developed an empirical study on causal relationship between perceived enjoyment and perceived ease of use. Perceived enjoyment and ease of use are conceptually close in the nature so it is difficult to distinguish their impacts from each another. Again ${ }^{28}$, have proposed both directions between PE and PEOU. They explained that the causal relationship is critical to understand the mechanism through the factors that infulence each other. However, this research confirms the hypothesis that PE affects PEOU and PU. Selfefficacy relates on the belief of each individual to perform a specific task and related to social cognitive theory of the human behavior.

Based on the previous studies above, the researcher develops three hypotheses as follow:

H1a: Enjoyment has significant effect on perceived usefulness to adopt e-travel

H1b: Enjoyment has significant effect on perceived ease of use in operating e-travel

H1c: Enjoyment has significant effect on self efficacy in operating e-travel

\subsubsection{Perceived Ease of Use and Usefulness}

There is some research investigated toward success model based on user's perceptions. Easy to use and usefulness are used in TAM (technological acceptance model) theory as the base model ${ }^{29}$. The research by ${ }^{30}$ and ${ }^{31}$ was tested relationships between easy of use and usefulness. The research found that the relationship is significant. Therefore, the researcher exam the relationship between perceived of use and perceived usefulness. Based on the previous studies above, the researcher develops a hypothesis as follow:

H2: Perceived ease of use has significant effect on perceived usefulness using e-travel.

\subsubsection{Impact Usefulness, Ease of Use, Self Efficacy on Use of E-travel Website}

The prior studies tested the relationship between variables perceived Usefulness, Ease of Use, Self Efficacy and the use of e-travel website. There are also researchers testing the direct effect of perceived these variables to the usage variables ${ }^{32}$. The results support their suggestion these varibles have significantly affect the usage website.

However, there is also research which does not support this relationship. Ndubisi \& Jantan ${ }^{33}$ found that perceived ease of use does not influence the use of information system by Malaysian small and mediumsized firms. It is found that Perceived ease of use indirectly influence the use of IS through the role of mediating variable which is perceived usefulness ${ }^{33}$. Based on the previous studies above, the researcher develops hypotheses as follow:

\section{H3a: Perceived ease of use has significant effect on the use of e-travel website}

H3b: Perceived Usefulness has significant effect on the use of e-travel website

H3c: Self Efficacy has significant effect on the use of etravel website

\subsubsection{Actual Use, User Satisfaction, Trust and Loyalty}

A research that investigated the impact of personal system characteristics, technical banking and computing skill on information system (IS) usage of Malaysian small medium firms $(\mathrm{SMF})^{33}$. The research revealed actual usage of information system by Malaysian small and medium firms is driven directly by their perception of the system's usefulness, acquired computing skills, and technical backing provided by systems designers or vendors ${ }^{33}$.

As reported in previous studies ${ }^{34,35,36,37}$ use has significant influence on user satisfaction. The more customers use your site, the more experience they have with your site, the more they like your site, the more they will revisit your site. It indicates that website use ia an imperative factor to build the user satisfaction of a website. Indonesian SMEs' websites should encourage users' use of their sites by providing flexible services and facilities (i.e., checking order status and inventory online, ordering online but paying and picking up offline, ordering online and exchanging and return offline) as well as providing some incentives (e.g., vouchers and discounts for first-time users and for referring other customers to their sites, etc).

Loyalty is an attitude or a combination of attitude and behavior. According to the approach based on behavior, loyalty is a behavioral reaction based on prejudice as the function of psychological processes to make decisions with existence at a particular time. Behavioral approach explained loyalty basing on the criteria including the share in consumption probability, probability to consume the product again, repeat consumption behavior, multidirectional consumption behaviors (Kumar \& Shah, 204).

Trust is crucial factor in affecting relationship commitment and customer loyalty. The impact of the 
customeres perception on service provider, influence the trust on the loyalty and the customers satisfaction significantly. Trust as an element of customer satisfaction has an influence on building customer loyalty (Chen and Xie, 2007). Based on the previous studies above, four hypotheses developed as follow:

H4: Actual Use has significant effect on the user satisfactions of e-travel website
H5: User satisfaction has significant effect on trust of etravel website

H6: User satisfaction has significant effect on loyalty of e-travel website

H7: Trust has significant effect on loyalty of e-travel website

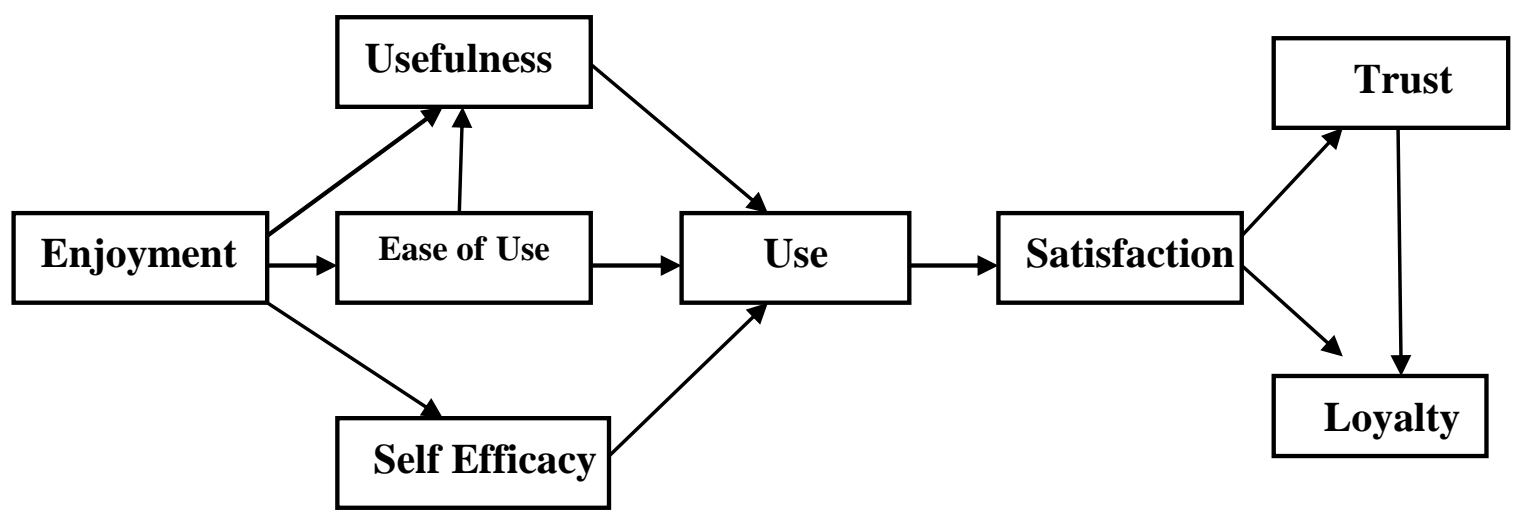

Figure 1. Research Model of E-travel Adoption

\section{Methodology}

This research was done with the objects and methods that differ based on the research objective which will look for the answer. The first research objective, research activities will be followed by identifying the success factors of travel websites in Indonesia, with an empirical study of travel agencies in using e-travel. The research is started from identifying the success factors of travel website uses in Padang employing an online survey technique. Before doing the data collection, the preparation of research instrument was conducted. There are some procedures to arrange the instrument;

a. Indentify each variable' indicators to build construct of research model based on previous study

b. Each variable indicator was translated to Bahasa as research instrument and questionnaires.

c. The questionnaire was reviewed to improve the quality of instrument especially to ascertain a feasible tool of online survey.

d. The revised questionnaire was put in online survey using the website template of my3q.com. The address domain is http://www.my3q.com/survey/480/risetln/72449.pht $\underline{\mathrm{ml}}$ (in Bahasa) and http://www.my3q.com/survey/480/risetln/65607.pht $\underline{\text { ml (In English) }}$ e. The accomplished template of online survey for the current research was launched.

The current research identifies success factors from small travel enterprises (STEs). The data is collected by online survey to website travel users. The procedures of data collection are:

1. The fulfilled questionnaire by website users was sent back to risetln@gmail.com. and was concluded in an excel form of survey reports in my3q website hosted.

2. The excel report displayed the raw data of current research and was processed using quantitative technique as the data analysis using Structurl Equation Modeling (SEM) with SmartPLS software.

The quantitative research employing online survey to travel website users in Indoneisa was undertken. The returned questionnaires of this survey were 145 Indonesian website users during 3 months.

\section{Results}

\subsection{Test of Instrument (Outer Model)}

\subsubsection{Test of Validity}

This research is used software PLS to test the validity of reflective indicators of each variable are used. The 
results of testing the instrument validity were evaluated based on convergent validity and discriminant validity, the charge indicators will be measured from the value of outer loading through the process of the algorithm. The indicator is considered valid if it has value of outer loading up 0.70. However, for loading the $0.50-0.70$ is still acceptable as long as the value of communality AVE and 0.50 .

The results of loading score shows that there is one indicator that measures the dimensions on the enjoyment which has a value of variable loading below 0.50 i.e. EY5 indicator $(0,406539)$; travel website can be used as a way to fill the time. The invalid indicators will be removed in this research because the value of the outer loading $<0.5$ although score AVE and communality $>0.5$. The value of AVE and communality already meet the required testing convergent validity, i.e. greater than 0.50 . Furthermore, the invalid indicator (EY5) will be removing from the model testing instruments and then research model will be run again (revised). The values of the outer loading after all invalid indicators have been deleted. The instrument of validity test in this research uses discriminant validity. To determine the instrument of discriminant validity it can see from the value of cross loading, by comparing the indicator correlation of that constructs with the other constructs. Table 4.1. It shows the value of the discriminant validity of the cross loading test research in Indonesia.

Table 4.1. Cross Loading

\begin{tabular}{|c|c|c|c|c|c|c|c|c|}
\hline ITEMS & $\begin{array}{c}\text { ENJOY- } \\
\text { MENT }\end{array}$ & LOYALTY & $\begin{array}{c}\text { EASE OF } \\
\text { USE }\end{array}$ & $\begin{array}{l}\text { USEFUL- } \\
\text { NESS }\end{array}$ & $\begin{array}{l}\text { SELF } \\
\text { EFFC }\end{array}$ & $\begin{array}{l}\text { SATISFAC- } \\
\text { TION }\end{array}$ & TRUST & USE \\
\hline EY1 & 0,860912 & 0,459602 & 0,518583 & 0,573802 & 0,497922 & 0,474210 & 0,381107 & 0,494108 \\
\hline EY2 & 0,762913 & 0,392998 & 0,338992 & 0,440435 & 0,350498 & 0,361991 & 0,319477 & 0,430719 \\
\hline EY3 & 0,889970 & 0,509743 & 0,573952 & 0,523070 & 0,479600 & 0,467148 & 0,407640 & 0,445833 \\
\hline EY4 & 0,836545 & 0,508422 & 0,579587 & 0,515220 & 0,505147 & 0,458657 & 0,411315 & 0,429797 \\
\hline LY1 & 0,375747 & 0,865934 & 0,485367 & 0,490006 & 0,622589 & 0,631544 & 0,530412 & 0,523609 \\
\hline LY2 & 0,488510 & 0,886710 & 0,584788 & 0,519506 & 0,616286 & 0,660938 & 0,554810 & 0,556647 \\
\hline LY3 & 0,560708 & 0,829312 & 0,594136 & 0,535639 & 0,569962 & 0,569727 & 0,506730 & 0,532018 \\
\hline LY4 & 0,460217 & 0,724470 & 0,444114 & 0,399817 & 0,440759 & 0,399907 & 0,324454 & 0,422663 \\
\hline PEOU1 & 0,399702 & 0,448746 & $\mathbf{0 , 7 5 7 5 2 7}$ & 0,516386 & 0,506439 & 0,504233 & 0,488376 & 0,326645 \\
\hline PEOU2 & 0,479458 & 0,558039 & 0,852867 & 0,653965 & 0,585341 & 0,535694 & 0,491445 & 0,425300 \\
\hline PEOU3 & 0,570615 & 0,538959 & 0,820614 & 0,638315 & 0,494022 & 0,502354 & 0,389441 & 0,422657 \\
\hline PEOU4 & 0,402943 & 0,347064 & 0,660872 & 0,519747 & 0,280273 & 0,362770 & 0,354473 & 0,260461 \\
\hline PEOU5 & 0,409643 & 0,462393 & 0,654310 & 0,422541 & 0,479370 & 0,547864 & 0,575628 & 0,456458 \\
\hline PEOU6 & 0,488683 & 0,515533 & $\mathbf{0 , 7 7 6 3 5 0}$ & 0,509819 & 0,538072 & 0,493470 & 0,474407 & 0,535514 \\
\hline PU1 & 0,444804 & 0,389694 & 0,486111 & 0,645290 & 0,469262 & 0,419389 & 0,461822 & 0,370913 \\
\hline PU2 & 0,392407 & 0,368855 & 0,572450 & 0,711177 & 0,402088 & 0,379120 & 0,428785 & 0,284290 \\
\hline PU3 & 0,507960 & 0,489309 & 0,468684 & 0,664236 & 0,505225 & 0,420624 & 0,362109 & 0,459930 \\
\hline PU4 & 0,467694 & 0,470231 & 0,578636 & 0,802868 & 0,511822 & 0,391137 & 0,348098 & 0,476639 \\
\hline PU5 & 0,492575 & 0,392618 & 0,566030 & 0,822240 & 0,481796 & 0,319685 & 0,350855 & 0,368267 \\
\hline PU6 & 0,461345 & 0,428254 & 0,578141 & $\mathbf{0 , 8 0 3 0 4 3}$ & 0,480706 & 0,365211 & 0,461329 & 0,367081 \\
\hline PU7 & 0,404533 & 0,507155 & 0,485462 & $\mathbf{0 , 7 0 7 7 3 4}$ & 0,546906 & 0,441659 & 0,465845 & 0,391705 \\
\hline SE1 & 0,316554 & 0,436143 & 0,371694 & 0,468816 & 0,723996 & 0,412689 & 0,437286 & 0,593930 \\
\hline SE10 & 0,474694 & 0,567972 & 0,552174 & 0,546030 & 0,752129 & 0,533948 & 0,495209 & 0,580905 \\
\hline SE11 & 0,523437 & 0,630967 & 0,599334 & 0,562218 & $\mathbf{0 , 8 2 3 4 2 7}$ & 0,486489 & 0,410692 & 0,540693 \\
\hline SE12 & 0,416022 & 0,545286 & 0,460135 & 0,485472 & 0,761685 & 0,419730 & 0,412302 & 0,506412 \\
\hline SE2 & 0,409797 & 0,470630 & 0,479630 & 0,515179 & 0,768862 & 0,407130 & 0,462250 & 0,534685 \\
\hline
\end{tabular}




\begin{tabular}{clllllllll} 
SE3 & 0,433590 & 0,464297 & 0,480985 & 0,442626 & $\mathbf{0 , 6 6 2 3 7 2}$ & 0,377739 & 0,364761 & 0,548850 \\
SE4 & 0,385455 & 0,460825 & 0,473469 & 0,397547 & $\mathbf{0 , 7 6 4 1 1 5}$ & 0,396891 & 0,396081 & 0,594150 \\
SE5 & 0,345970 & 0,502228 & 0,461459 & 0,477544 & $\mathbf{0 , 7 6 5 2 3 1}$ & 0,451352 & 0,504354 & 0,485038 \\
SE6 & 0,490649 & 0,561728 & 0,499588 & 0,579005 & $\mathbf{0 , 8 1 5 8 3 9}$ & 0,500133 & 0,482486 & 0,485334 \\
SE7 & 0,454280 & 0,531516 & 0,473342 & 0,554459 & $\mathbf{0 , 7 6 6 8 3 4}$ & 0,444198 & 0,427693 & 0,503736 \\
SE8 & 0,376410 & 0,532635 & 0,485688 & 0,520371 & $\mathbf{0 , 7 2 8 1 5 7}$ & 0,450798 & 0,487305 & 0,518737 \\
SE9 & 0,325228 & 0,478299 & 0,414174 & 0,358561 & $\mathbf{0 , 6 8 4 0 0 4}$ & 0,443312 & 0,426694 & 0,431814 \\
ST1 & 0,450196 & 0,570928 & 0,520393 & 0,411488 & 0,526659 & $\mathbf{0 , 8 7 0 3 4 4}$ & 0,695563 & 0,469495 \\
ST2 & 0,457368 & 0,637833 & 0,603425 & 0,445936 & 0,529295 & $\mathbf{0 , 9 2 4 2 5 5}$ & 0,673476 & 0,513567 \\
ST3 & 0,513216 & 0,659550 & 0,615611 & 0,556387 & 0,529379 & $\mathbf{0 , 8 8 9 3 2 5}$ & 0,697049 & 0,457973 \\
TR1 & 0,375601 & 0,401050 & 0,503830 & 0,452539 & 0,464364 & 0,521058 & $\mathbf{0 , 7 2 7 0 5 7}$ & 0,426703 \\
TR2 & 0,361866 & 0,476381 & 0,448801 & 0,454190 & 0,435613 & 0,647391 & $\mathbf{0 , 8 1 3 1 1 9}$ & 0,422439 \\
TR3 & 0,327672 & 0,472993 & 0,468937 & 0,451594 & 0,475163 & 0,557329 & $\mathbf{0 , 8 2 1 0 6 7}$ & 0,417191 \\
TR4 & 0,392329 & 0,526105 & 0,518135 & 0,418536 & 0,501030 & 0,708490 & $\mathbf{0 , 8 2 9 4 6 7}$ & 0,446387 \\
USE1 & 0,354799 & 0,569006 & 0,286875 & 0,364090 & 0,532185 & 0,389027 & 0,288284 & $\mathbf{0 , 6 0 1 1 5 6}$ \\
USE2 & 0,395099 & 0,402314 & 0,441542 & 0,380329 & 0,546214 & 0,391898 & 0,410138 & $\mathbf{0 , 8 0 1 6 1 5}$ \\
USE3 & 0,425768 & 0,414933 & 0,389779 & 0,419116 & 0,520609 & 0,434698 & 0,427726 & $\mathbf{0 , 7 9 9 0 6 8}$ \\
USE4 & 0,406794 & 0,445967 & 0,478360 & 0,401011 & 0,479794 & 0,369494 & 0,456270 & $\mathbf{0 , 7 4 9 3 0 7}$ \\
\hline
\end{tabular}

Source: developed by this research (2014)

Discriminant validity is used to indicate that the construct or latent variable can predict the size of their blocks is better than other block size. The construct indicator correlation has a higher value than the correlation of these indicators to the other constructs, then it says that the constructs have high discriminant validity. The result shown that all of the indicators already have a higher correlation value to the variable tested them than other variables, consequently, all items meet the validity.

The discriminant validity is not only can be viewed from the value of cross-loading but also can be seen by comparing the root of AVE (Square Root of Average) a construct must be higher than the correlation between latent variables (Chin and Newsted, 1999) (Table 4.2). The Model has a discriminant validity is sufficient if the root AVE for any invalid constructs larger than the correlation between invalid constructs and other invalid constructs in the model. The value of the root AVE can be seen in Table 4.3. The comparison of the value of the root for each variable with AVE correlations between variables in table 3.3 shows that each of root value AVE (in bold) on the variables of greater correlation between variables as compared to others, so it can be said that the entire latent variable has a good discriminant validity.

Table 4.2 present the measurement of validity as loading and AVE score and also Latent Variable Correlations (AVE square) in Table 4.3.

Tabel 4.2. Loading Score and AVE

\begin{tabular}{clllll}
\hline Variabel & Indikator & & Description & Loading & AVE \\
\hline \multirow{2}{*}{ Enjoyment } & EY1 & Have fun & 0,860912 & \\
& EY2 & Pleasant & 0,752913 & 0,703765 \\
& EY3 & Enjoyable & 0,889970 & \\
& EY4 & Exciting & 0,836545 & \\
\hline \multirow{2}{*}{ Self Efficacy } & SE1 & Ability to use & 0,723996 & 0,566592
\end{tabular}




\begin{tabular}{|c|c|c|c|c|}
\hline & SE3 & Fill up forms & 0,662372 & \\
\hline & SE4 & Download & 0,764115 & \\
\hline & SE5 & Send email & 0,765231 & \\
\hline & SE6 & Communicate & 0,815839 & \\
\hline & SE7 & Use favorite & 0,766834 & \\
\hline & SE8 & No around to tell & 0,728157 & \\
\hline & SE9 & Trouble shooting problem & 0,684004 & \\
\hline & SE10 & Confident though never use before & 0,752129 & \\
\hline & SE11 & Confident finding information & 0,823427 & \\
\hline & SE12 & Necessary skills & 0,761685 & \\
\hline \multirow{6}{*}{ Ease of Use } & PEOU1 & Learning to operate & 0,757527 & \multirow{6}{*}{0,573705} \\
\hline & PEOU2 & Flexible to interact & 0,852867 & \\
\hline & PEOU3 & Easy to do what to do & 0,820614 & \\
\hline & PEOU4 & Become skillful & 0,660872 & \\
\hline & PEOU5 & Easy to use & 0,654310 & \\
\hline & PEOU6 & Clear and understandable & 0,776350 & \\
\hline \multirow{7}{*}{ Usefulness } & PU1 & Better decision & 0,645290 & \multirow{7}{*}{0,547118} \\
\hline & PU2 & Improve performance & 0,711177 & \\
\hline & PU3 & Quick Information & 0,664236 & \\
\hline & PU4 & Useful in job & 0,802868 & \\
\hline & PU5 & Increase productivity & 0,822240 & \\
\hline & PU6 & Increase effectiveness & 0,803043 & \\
\hline & PU7 & Easier job & 0,707734 & \\
\hline \multirow{4}{*}{ Use } & USE1 & Information search & 0,601156 & \multirow{4}{*}{0,550986} \\
\hline & USE2 & Customer service request & 0,801615 & \\
\hline & USE3 & Purchase order & 0,799068 & \\
\hline & USE4 & Payment order & 0,749307 & \\
\hline \multirow{3}{*}{ Satisfaction } & ST1 & Satisfied & 0,870344 & \multirow{3}{*}{0,800881} \\
\hline & $\mathrm{ST} 2$ & Successful & 0,924255 & \\
\hline & ST3 & Expectation & 0,889325 & \\
\hline \multirow{4}{*}{ Trust } & TR1 & Not opportunistics & 0,727057 & \multirow{4}{*}{0,637985} \\
\hline & TR2 & Cares & 0,813119 & \\
\hline & TR3 & Honest & 0,821067 & \\
\hline & TR4 & Predictable & 0,829467 & \\
\hline \multirow{4}{*}{ Loyalty } & LY1 & Recommend the online organization & 0,865934 & \multirow{4}{*}{0,687178} \\
\hline & LY2 & Recommend the organization's webs & 0,886710 & \\
\hline & LY3 & Intend to continue using & 0,829312 & \\
\hline & LY4 & Prefer than others & 0,724470 & \\
\hline
\end{tabular}

Source: developed by this research (2014) 
Tabel 4.3. Latent Variable Correlations (AVE square)

\begin{tabular}{|c|c|c|c|c|c|c|c|c|}
\hline & $\begin{array}{c}\text { EASE OF } \\
\text { USE }\end{array}$ & $\begin{array}{c}\text { ENJOY- } \\
\text { MENT }\end{array}$ & LOYALTY & $\begin{array}{l}\text { SATISFAC- } \\
\text { TION }\end{array}$ & $\begin{array}{l}\text { SELF } \\
\text { EFFC }\end{array}$ & TRUST & USE & $\begin{array}{l}\text { USEFUL- } \\
\text { NESS }\end{array}$ \\
\hline EASE OF USE & $\mathbf{0 , 7 5 7 4 3 3}$ & & & & & & & \\
\hline ENJOYMENT & 0,611308 & $\mathbf{0 , 8 3 8 9 0 7}$ & & & & & & \\
\hline LOYALTY & 0,638227 & 0,561473 & 0,828962 & & & & & \\
\hline SATIS & 0,648843 & 0,529582 & 0,696722 & 0,894919 & & & & \\
\hline SELF EFFC & 0,640818 & 0,553451 & 0,686826 & 0,590478 & 0,752723 & & & \\
\hline TRUST & 0,605599 & 0,456048 & 0,591216 & 0,769399 & 0,586477 & 0,798739 & & \\
\hline USE & 0,539661 & 0,535526 & 0,617835 & 0,536857 & 0,703714 & 0,535362 & 0,742284 & \\
\hline USEFULNESS & 0,723313 & 0,615186 & 0,590031 & 0,527626 & 0,657869 & 0,552840 & 0,529262 & 0,739674 \\
\hline
\end{tabular}

Source: developed by this research (2014)

Tabel 4.4. Cronbach's Alpha and Composite Realibility

\begin{tabular}{lcc}
\hline \multicolumn{1}{c}{ Variables } & Composite Reliability & Cronbachs Alpha \\
\hline EASE OF USE & 0,888846 & 0,848864 \\
ENJOYMENT & 0,904515 & 0,859667 \\
LOYALTY & 0,897298 & 0,849062 \\
SATISFACTION & 0,923424 & 0,875341 \\
SELF EFFC & 0,939875 & 0,929970 \\
TRUST & 0,875475 & 0,810647 \\
USE & 0,829034 & 0,721085 \\
USEFULNESS & 0,893477 & 0,859716 \\
\hline
\end{tabular}

\subsubsection{Reliability Test}

Reliability test was done to find out the extent of the measurement tools. It illustrates the accuracy and precision of measurement that are consistent over time. The Instrument reliability in this research is determined by the value of cronbach's alpha and composite reliability for each block of indicators on reflective invalid constructs. Rule of thumb value cronbach's alpha and composite reliability must be greater than 0.7 value though 0.6 still acceptable (Cooper and Schindler, 2008). Cronbach's alpha compositing and reliability of each variable are examined it can be seen in Table 4.4 in Indonesia.

\subsection{Structural Measurement (Inner Model)}

\subsubsection{Hypothesis Testing}

Structural Model consist of the latent constructs that can not be observed that have related to the theory. This testing includes estimating the coefficient that identifies the strength correlation between dependent variable and independents. Structural model testing produce the significant value of the relationship between latent variable path by using bootstrapping function.

The coefficients value of each line can be seen from the original sample value of constructs. The value of path coefficient or inner models indicates the level of significance in hypothesis testing. Score of path coefficient or inner model that indicated by a T-statistic value, should be above the 1.96 for two-tailed hypothesis and above the 1.64 for one-tailed hypothesis to test hypotheses on alpha 5 percent (Hair et al., 2007).

Structural model testing from the above research model figure can be seen summarized in Table 4.5. Table 4.5 shows the significance of paths among variables in the structural model of $t$ statistics among variables. Each independent variable that is tested in this structural model study had an impact on its dependent variable. It is proven by the value of $\mathrm{T}$ statistics that are all greater than 1.96 (for a two-tail 
test). Test relationships between variables showed that the influence of ease of use variables on the use is positive $(0,540245)$ and significant at $\alpha=0.05$ with statistical value $9,451317>1.96$. Ease of use variable has positive effect on the usefulness $(0,604166)$ and significant at $\alpha=0.05$ with statistical value $9,148326>$ 1.96.

Enjoyment has a positive effect on ease of use $(0,596413)$ and significant at $\alpha=0.05$ with statistical value $12,102668>1.96$. The impact of usefulness on enjoyment is also positive $(0,603803)$ and significant at $\alpha=0.05$ with statistical value $12,032851>1.96$. Use has positive effect on satisfaction $(0,590088)$ and significant at $\alpha=0.05$ with statistical value $8,971423>$ 1.96. The influence of usefulness variable is also positive to use $(0,209215)$ and significant at $\alpha=0.05$ with statistical value $2,010346>1.96$. The results of each hypothesis testing as a whole is seen in Table 4.5 below.

Table 4.5. Hypothesis Test

\begin{tabular}{cll}
\hline Hypothesis & \multicolumn{1}{c}{ Statement } & \multicolumn{1}{c}{ Results } \\
\hline H1a & Enjoyment has a positive influence to ease of use & Supported * \\
H1b & Enjoyment has a positive influence to usefulness & Supported * \\
H1c & Enjoyment has a positive influence to self efficacy & Supported * \\
H2 & Ease of use has a positive influence to usefulness & Supported * \\
H3a & Ease of use has a positive influence to use & Supported * \\
H3b & Usefulness has a positive influence to use & Not Supported \\
H3c & Self efficacy has a positive influence to use & Supported * \\
H4 & Use has a positive influence to satisfaction & Supported * \\
H5 & Satisfaction has a positive influence to trust & Supported * \\
H6 & Satisfaction has a positive influence to loyalty & Supported * \\
H7 & Trust has a positive influence to loyalty & Not Supported \\
\hline
\end{tabular}

The current research shown the factor of enjoyment, usefulness, ease of use, actual use dan user's satisfaction have significant impact on e-travel in Indonesia contexts. In the meantime, the factor of Usefulness and Trust have a insingnificant impact on E-travel adoption in Indonesia.

\section{Conclusion}

This research investigated empirically the web site success model for small travel agents in Indonesia contexts. The result predicted that using e-travel among small travel enterprises (STEs) in Indonesia might concern about factors related to enjoyment, self efficacy, ease of use and usefulness during visits travel websites.

The current research shown the factor of enjoyment, usefulness, ease of use, actual use dan user's satisfaction has significant impact on e-travel in Indonesia contexts. However, the factor of Usefulness and Trust has insignificant impacts on E-travel adoption in Indonesia.
There were the numerous of considerate decision to improve the website usability and features which would be able to satisfy, be trust and loyal for website users/potential customers. This research is more concern toward user's behaviour during surfing in the website rather than the quality of its technology. The final findings of e-travel success model will be expected to give contributions to travel agents in the country. This finding also is expected to contribute to business practices and can assist Indonesian managers operating their own web sites to be more effective and efficient.

For the further research, examining the success model of e-travel adoption in different provinces and travel websites would be suggested.

\section{Acknowledgements}

The authors are grateful to Indonesia and Minister of Indonesian Higher Education (Dikti-DP2M) for giving the financial support of this research as International Research Collaboration grant and scientific Publication for three years since 2012-2014. 


\section{References}

1. B. Widrow and S. d. Steams, Adaptive Signal Processing (Prentice Hall, Englewood, NJ, 1995).

2. R. Loren and D. B. Benson (eds.), Introduction to String Field Theory, 2nd edn. (Springer-Verlag, New York, 1999).

3. R. M. Karp, Reducibility among combinatorial problems, in Complexity of Computer Computations (Plenum, New York, 1972), pp. 85-104.

4. R. Loren and D. B. Benson, Deterministic flow-chart interpretations, J. Comput. System Sci. 27(2) (1983) 400433.

5. R. Loren, J. Li and D. B. Benson, Deterministic flowchart interpretations, in Proc. 3rd Int. Conf. EntityRelationship Approach, eds. C. G. Davis and R. T. Yeh (North-Holland, Amsterdam, 1983), pp. 421-439.

6. T. Van Vuuren, M. Roberts-Lombard, and E. Van Tonder, "Customer satisfaction, trust and commitment as predictors of customer loyalty,"Southern African Business Review, vol. 16, no. 3, 2012.

7. A.-K. M. Mufaddy, D. Subhasish, and A.-F. A. Hmoud, "Factors Affecting E-service Satisfaction," IBIMA Publishing, Communications of the IBIMA, 2011.

8. Z. Moshe, G. Chanan, and A. Itay. (2005). User Satisfaction from Commercial Web Sites: The effect of design and use. Information and Management. [Online]. Available: www.sciendirect.com.

9. B. Angelova and J. Zekiri, "Measuring customer satisfaction with service quality using American customer satisfaction model (ACSI model)," International Journal of Academic Research in Business and Social Sciences vol. 1, no. 3, 2011.

10. W. H. Delone and E. R. McLean, "Measuring ecommerce success: Applying the delone \& mclean information system success model," International Journal of Electronic Commerce, vol. 9, no. 1, pp. 31-41, 2004.

11. N. K. Juliet, "Perceived usefulness, perceived ease of use, behavioral intention to use and actual system usage in centenary bank," Mastergraduate dissertation, Master of Science of accounting and finance of Makere University, Kamapala, 2011.

12. D. Davis, "Perceived usefulness, perceived ease of use, and user acceptance of information technology," MIS Quarterly, vol. 13, no. 3, pp. 319-340, 1989.

13. Joshua, N., Pujani, V., 2014, Customer Satisfaction in Using e-Travel: The Role of Self Efficacy, Trust, and Use, International Journal of Trade, Economics and Finance, Vol. 5, No. 5, pp. 459-462.

14. Fatin, P.N., Pujani, V., 2014, Tour and Travel Website Beliefs in Influencing Users Satisfaction; Case Study: Malaysia, International Journal of Trade, Economics and Finance, Vol. 5, No. 5, pp. 454-458.
15. Luarn \& Lin, 2003, A Customer Loyalty Model for EService Context, Journal of Electronic Commerce Research, Vol. 4, No. 4, pp. 156-167.

16. D. Gefen, E. Karahanna and D. W. Straube, "Trust and TAM in online shopping: an integrated model," MIS Quarterly, vol. 27, no. 1, pp. 1-40, 2003.

17. D. H. McKnight and N. L. Chervany, "What trust means in ecommerce customer relationships: an interdisciplinary conceptualtypology," Management Science, vol. 46, no. 2, pp. 186-204, 2000.

18. Y. Chen and J. Xie, "Cross-market network effect with asymmetric customer loyalty: implications for competitive advantage," MarketingScience, vol. 26, no. 1, p. 52,2007 